\title{
Parasites of the relict fauna of Ceylon
}

\section{New species of Nematodes from Uropeltid snakes}

\author{
by H. CRUSZ and C. C. CHING \\ Department of Zoology, University of Sri Lanka, \\ Peradeniya, Sri Lanka
}

\section{Summary}

Two new species of nematodes have been found in endemic snakes of the family Uropeltidae which is restricted to montane regions in India and Sri Lanka.

A trichostrongylid, Oswaldocruzia gansi sp. nov., is described from the small intestine of Rhinophis drummondhayi from Watawala $(1075 \mathrm{~m})$ and the Namunukula area (1 200$1300 \mathrm{~m}), R$. philippinus from Pallatenne $(618 \mathrm{~m})$, and Uropeltis melanogaster from Kandy $(800+\mathrm{m})$. It is distinguished from other species of the genus chiefly by the trifurcate nature of the distal end of its dorsal ray and the number of terminal processes of each spicule.

A cosmocercid, Aplectana uropeltidarum sp. nov., is described from the rectum of the same hosts as well as of Uropeltis phillipsi from Gammaduwa $(720 \mathrm{~m})$, and Rhinophis blythi from Talawakele $(1016 \mathrm{~m})$. It was also found in the rectum of Teretrurus sanguineus from the Nalumukku Estate, Mandjolai $(1524 \mathrm{~m})$ in S. India. It differs from all other species of the genus, especially in the number and arrangement of the caudal papillae of the male. 


\section{Résumé}

Parasites de la faune relique de Ceylan. V. Espèces nouvelles de Nématodes de serpents Uropeltides.

Deux espèces nouvelles de Nématodes ont été trouvées chez des serpents endémiques de la famille Uropeltidae qui ne se trouve que dans les régions montagneuses d'Inde et de Sri Lanka.

Nous décrivons un Trichostrongylide Oswaldocruzia gansi sp. nov., trouvé dans l'intestin grêle de Rhinophis drummondhayi récolté à Watawala $(1075 \mathrm{~m})$ et à la région de Namunukula (1 200-1 $300 \mathrm{~m})$, de $R$. philippinus récolté à Pallatenne $(618 \mathrm{~m})$ et d'Uropeltis melanogaster récolté à Kandy $(800+\mathrm{m})$. Il se distingue d'autres espèces du genre surtout par la trifurcation de l'extrémité du rayon dorsal et par le nombre des apophyses terminales de chaque spicule.

Nous décrivons aussi un Cosmocercide Aplectana uropeltidarum sp. nov., trouvé dans le rectum des hôtes mêmes, et d'Uropeltis phillipsi à Gammaduwa $(720 \mathrm{~m})$ et de Rhinophis blythi à Talawakele $(1016 \mathrm{~m})$. Cette espèce a été aussi trouvée dans le rectum de Teretrurus sanguineus à Nalumukku (Mandjolai, S. India) (1 $524 \mathrm{~m}$ ). Il diffère d'autres espèces du genre notamment par le nombre et la disposition des papilles caudales du mâle.

\section{Introduction}

« The Uropeltidae are a small group of burrowing snakes restricted to the mountains and foothills of Central India and Sri Lanka (Ceylon). »

Carl Gans, 1973.

In August 1972, and again in May and November 1974, we had the good fortune to have Professor Carl Gans of the Department of Zoology, University of Michigan, Ann Arbor, working in our region on certain snakes, mainly uropeltids, of which he brought to our laboratory live specimens of endemic Ceylonese species belonging to the genera Uropeltis and Rhinophis, and of a species of Teretrurus endemic to India.

These uropeltid snakes, freshly examined by us for their parasites, were found to be consistently infested with nematodes belonging to two new species, one, a trichostrongylid, in the small intestine, and the other, a cosmocercid, in the rectum. The results are summarised in Table $I$. 


$$
\text { PARASITES DE LA FAUNE RELIQUE DE CEYLAN }
$$
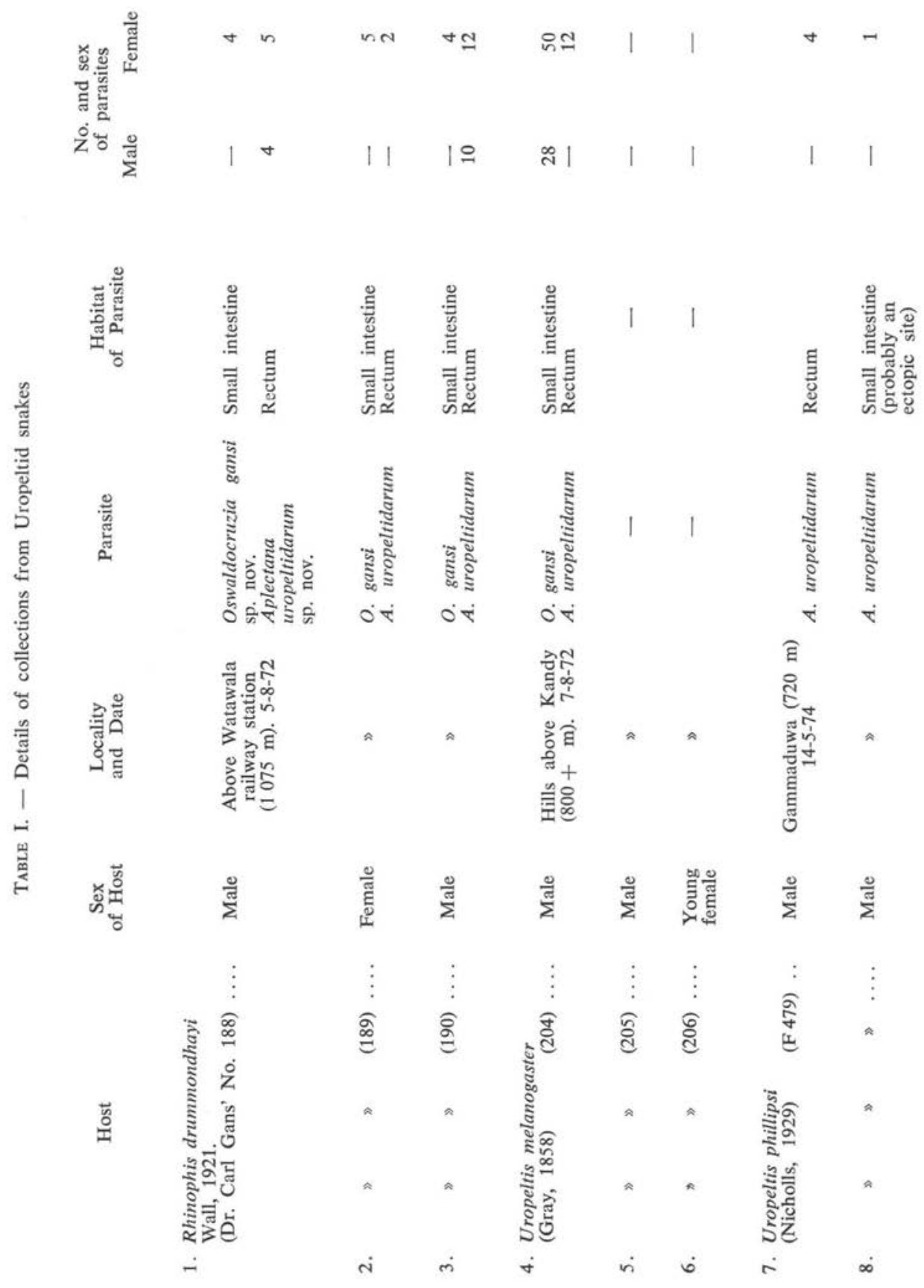


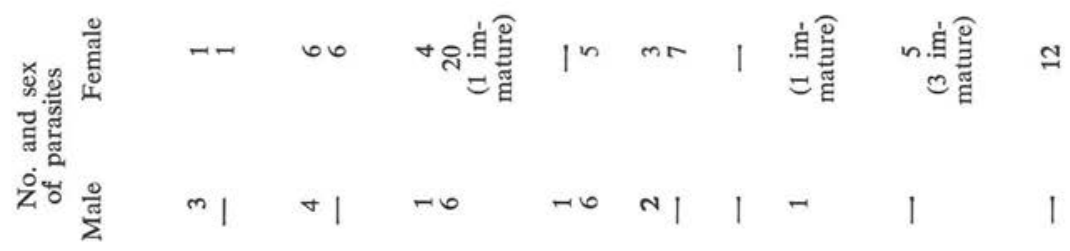

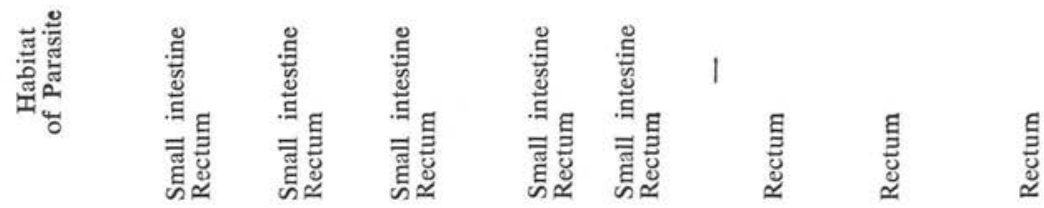

¿্ర<smiles>[CH]=[Co]</smiles>

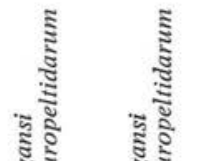

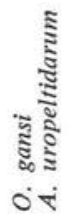

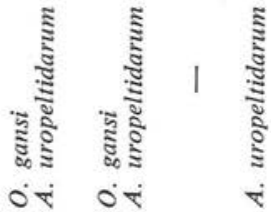

峞 ०ंx $\dot{0} \dot{x}$

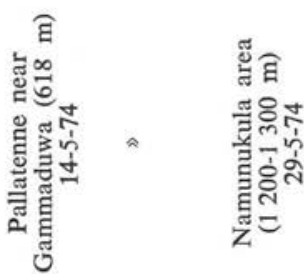

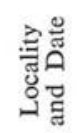

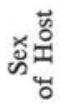
苂茞

芯

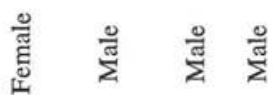

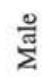
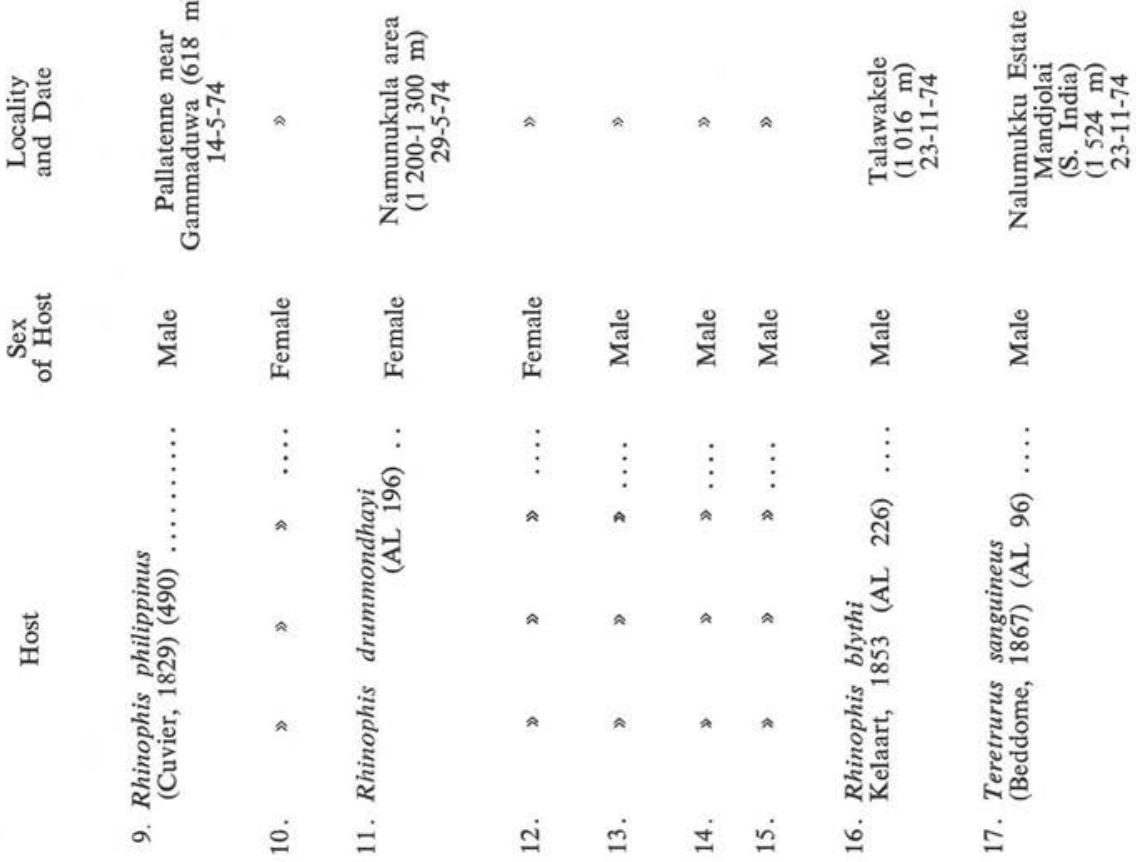

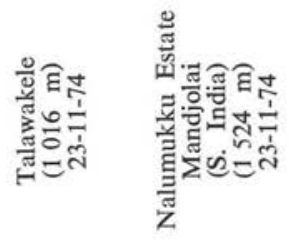




\section{Oswaldocruzia gansi sp. nov.}

(Strongylida : Trichostrongylidae)

(fig. 1-4)

\section{Deseription:}

The worms are long, thin and filiform. The cuticle is transversely striated and inflated at the head region (fig. 1). The mouth is terminal, with indistinct lips. The oesophagus is long and ends in a slightly defined bulb. The intestine is simple. The excretory pore is situated at about the level of the oesophageal bulb, just anterior to which is the nerve ring.

\section{Male:}

The males are provided with a well developed, symmetrical bursa (fig. 3 and 4). Prebursal papillae are absent. The dorsal lobe of the bursa is triangular. The ventral rays are equal and almost reach the bursal margin. The externo-laterals are thicker than the ventrals and are widely separated from the laterals near the tips. Mediolaterals and postero-laterals are equal, stout, separated from each other up to the base and reach the bursal margin. The externo-dorsal arises from a common trunk with the dorsal. The dorsal ray tapers distally and trifurcates. Just anterior to the trifurcation arise two larger branches. The spicules have four terminal processes, united by a membrane. A gubernaculum is absent.

$\mathrm{T}_{\mathrm{ABLE}}$ II. - Measurements (in $\mathrm{mm}$ ) of Oswaldocruzia gansi

\begin{tabular}{|c|c|c|}
\hline & Male (18) & Female (17) \\
\hline 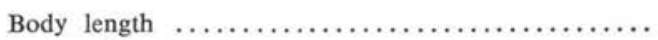 & $3.574-5.59$ & 4.13-7.798 \\
\hline 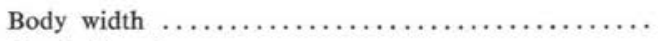 & $0.111-0.175$ & $0.135-0.191$ \\
\hline Head diameter $\ldots \ldots \ldots \ldots \ldots \ldots \ldots \ldots \ldots \ldots \ldots$ & $0.037-0.053$ & $0.033-0.049$ \\
\hline Oesophagus length $\ldots \ldots \ldots \ldots \ldots \ldots \ldots \ldots \ldots \ldots \ldots \ldots \ldots$ & $0.238-0.287$ & $0.299-0.328$ \\
\hline Bulb diameter $\ldots \ldots \ldots \ldots \ldots \ldots \ldots \ldots \ldots \ldots \ldots \ldots \ldots \ldots$ & $0.029-0.049$ & $0.033-0.053$ \\
\hline Nerve ring from anterior end $\ldots \ldots \ldots \ldots \ldots \ldots$ & $0.123-0.21$ & $0.164-0.213$ \\
\hline Excretory pore from anterior end $\ldots \ldots \ldots \ldots \ldots \ldots$ & $0.27-0.36$ & $0.28-0.32$ \\
\hline Spicule length $\ldots \ldots \ldots \ldots \ldots \ldots \ldots \ldots \ldots \ldots \ldots \ldots \ldots \ldots \ldots$ & $0.09-0.13$ & - \\
\hline Diameter of bursa $\ldots \ldots \ldots \ldots \ldots \ldots \ldots \ldots \ldots \ldots$ & $0.13-0.201$ & - \\
\hline Vulva from posterior end $\ldots \ldots \ldots \ldots \ldots \ldots \ldots$ & - & $2.68-3.5$ \\
\hline 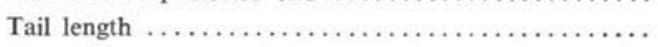 & - & $0.126-0.185$ \\
\hline \multirow{2}{*}{ Egg dimensions $\ldots \ldots \ldots \ldots \ldots \ldots \ldots \ldots \ldots \ldots \ldots \ldots \ldots$} & - & $0.053-0.127$ \\
\hline & & $0.033-0.074$ \\
\hline
\end{tabular}

\section{Female:}

The female worm is longer than the male worm. The tail of the female tapers down to a fine point (fig. 2). The vulva is in the posterior half of the body. Amphidelphic. The eggs are thin-shelled and elongated. The larvae are coiled. 


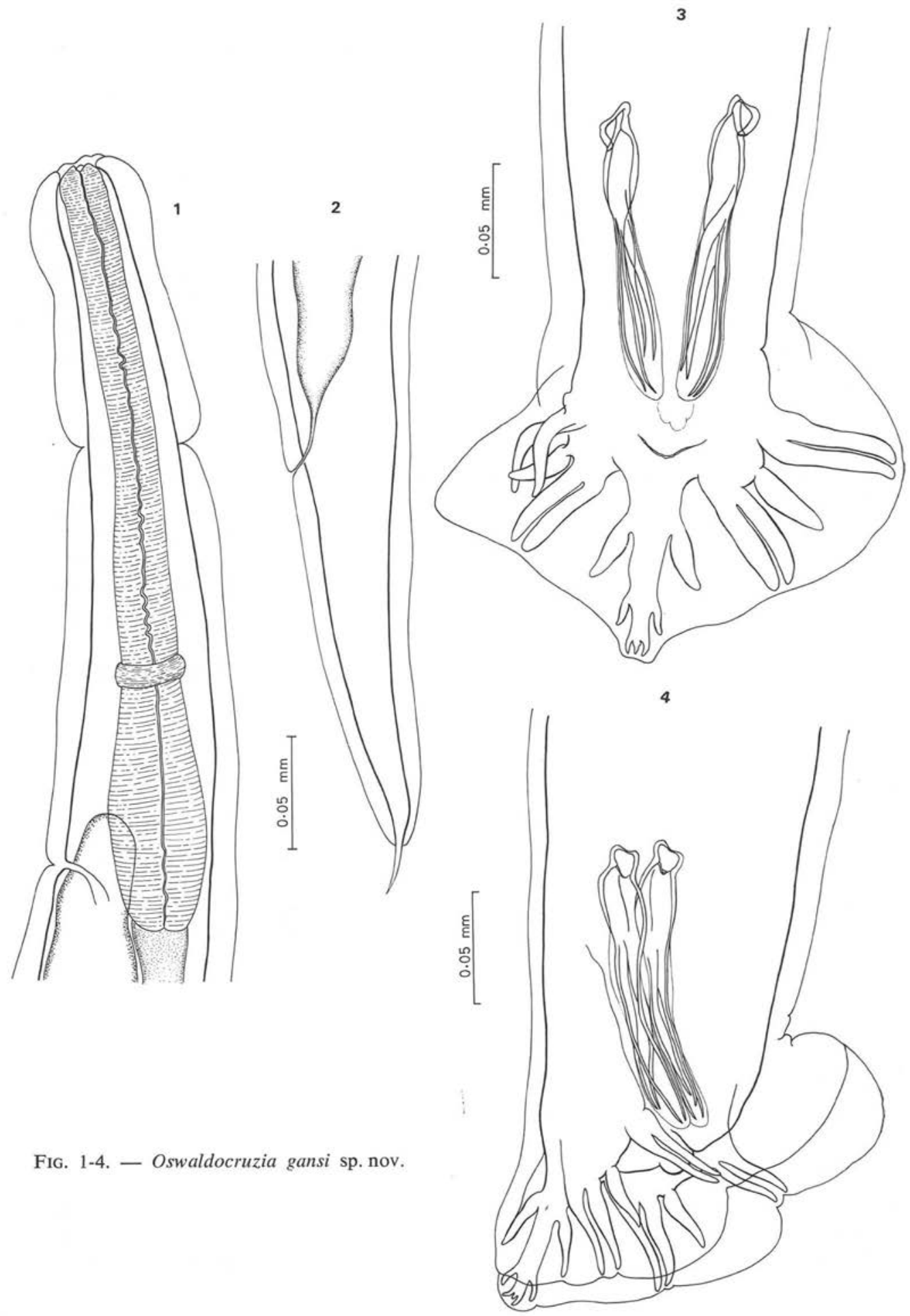




\section{Diseussion:}

The species described above comes closest to Oswaldocruzia legendrei Chabaud and Brygoo, 1962, and $O$. chamaeleonis Hörchner, 1963, both of which are described from chamaeleons in the Madagascar region. It differs from them however in the absence of longitudinal striations of the cuticle, in the postero-lateral and medio-lateral rays of the caudal bursa being separated from each other up to the base, in the trifurcation of the distal end of the dorsal ray, and in the number and shape of the terminal processes of each spicule. Furthermore, the small fleshy tongue at the base of the genital cone in the male, and the two short tubercles at the tail end of the female, of $O$. legendrei, and the papillae on the ventral and dorsal genital cone of the male of $O$. chamaeleonis, are wanting in the present form.

This species is therefore regarded as new and is named Oswaldocruzia gansi, in honour of D $^{r}$ Carl Gans.

\section{Type-specimens:}

The syntypes (Reg. No. RTS 37) are deposited in the Department of Zoology, University of Sri Lanka, Peradeniya.

\section{Aplectana uropeltidarum sp. nov.}

(Ascaridida : Cosmocercidae)

(fig. 5-7)

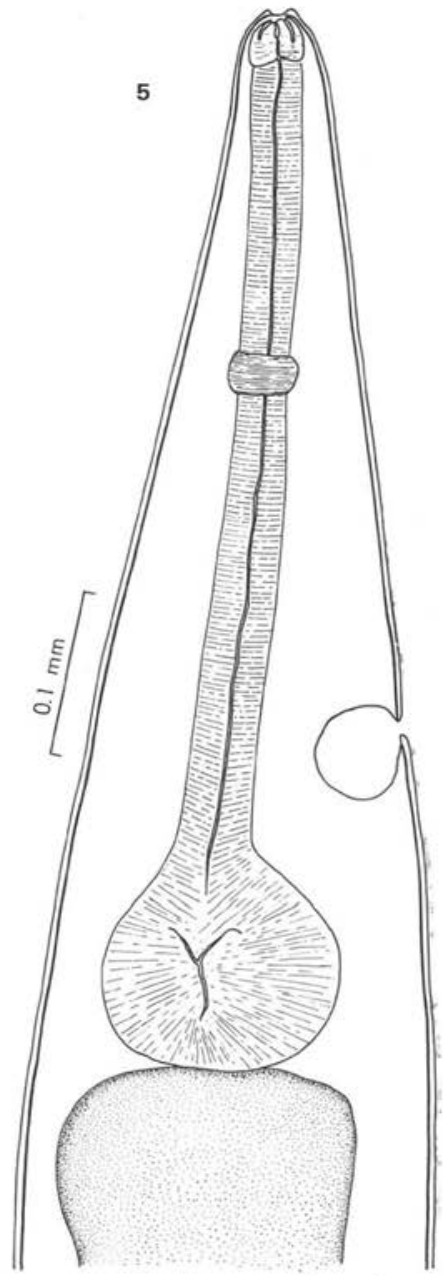

FIG. 5. - Aplectana uropelti-
darum sp. nov.

\section{Description:}

The worms are small and broad, with smooth cuticle, bluntly rounded anterior end and pointed posterior tail. Lateral alae extend from the anterior end to the end of the tail. These are clearly evident in serial transverse sections, 6 microns thick of 1 male and 3 female worms, stained in Ehrlich's haematoxylin and eosin. The mouth is terminal with three small triangular lips. The pharynx is poorly differentiated. The esophagus is well developed and ends in a muscular bulb (fig. 5). 
The nerve ring encircles the oesophagus and lies closer to the anterior end than to the level of the excretory pore. The excretory vesicle and pore are well developed and situated anterior to the oesophageal bulb. The intestine is simple and widest at its anterior end.

\section{Male:}

The tail of the male narrows and ends in a terminal spike (fig. 6). Ventrally there are 4-7 pairs of very large sessile papillae in the pre-cloacal region, and 3 pairs of smaller papillae in the post-cloacal region. Also ventral, and immediately above the anterior cloacal lip, are found 3 papillae, one median and one at each lateral end of the lip. There are, in addition, a few irregularly scattered, small papillae that extend, from about the level of the posteriormost pair of large pre-cloacal papillae, to the tip of the tail. The spicules are slender and equal in length. A triangular gubernaculum is present.

\section{Female:}

The tail, as in the male, ends in a terminal spike (fig. 7). The lateral alae are very prominent in this region. The vulva is situated just past the middle of the body. Prodelphic. The eggs are numerous, thin-shelled, slosely packed and embryonated.

TABLE III. - Measurements (in mm) of Aplectana uropeltidarum

$$
\begin{array}{ccc}
\text { Male (13) } & \begin{array}{l}
\text { Female (28) } \\
\text { (Sri Lanka) }
\end{array} & \begin{array}{l}
\text { Female (4) } \\
\text { (S. India) }
\end{array}
\end{array}
$$

\begin{tabular}{|c|c|c|c|}
\hline Body length & $1.59-2.39$ & 2.81-6.88 & $4.24-5.08$ \\
\hline Body width $\ldots \ldots \ldots \ldots \ldots \ldots \ldots \ldots \ldots \ldots \ldots \ldots \ldots \ldots \ldots \ldots \ldots$ & $0.175-0.234$ & $0.207-0.445$ & $0.302-0.413$ \\
\hline Head diameter $\ldots \ldots \ldots \ldots \ldots \ldots \ldots \ldots \ldots \ldots \ldots \ldots \ldots \ldots \ldots \ldots$ & $0.033-0.037$ & $0.029-0.041$ & $0.029-0.033$ \\
\hline Oesophagus length $\ldots \ldots \ldots \ldots \ldots \ldots \ldots \ldots \ldots \ldots \ldots$ & $0.361-0.418$ & $0.459-0.683$ & $0.524-0.762$ \\
\hline Bulb diameter $\ldots \ldots \ldots \ldots \ldots \ldots \ldots \ldots \ldots \ldots \ldots \ldots \ldots \ldots$ & $0.092-0.115$ & $0.127-0.175$ & $0.159-0.174$ \\
\hline Nerve ring from anterior end $\ldots \ldots \ldots \ldots \ldots \ldots$ & $0.123-0.172$ & $0.164-0.238$ & $0.168-0.213$ \\
\hline Excretory pore from anterior end $\ldots \ldots \ldots \ldots \ldots$ & $0.25-0.287$ & $0.283-0.492$ & $0.349-0.413$ \\
\hline Spicule length $\ldots \ldots \ldots \ldots \ldots \ldots \ldots \ldots \ldots \ldots \ldots \ldots \ldots \ldots$ & $0.131-0.147$ & - & - \\
\hline \multicolumn{4}{|l|}{ No. of papillae (pairs): } \\
\hline - pre-cloacal $\quad \ldots \ldots \ldots \ldots \ldots \ldots \ldots \ldots \ldots \ldots \ldots \ldots \ldots \ldots \ldots \ldots$ & 4-7 & - & 一 \\
\hline 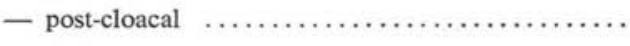 & 3 & & \\
\hline Tail length $\ldots \ldots \ldots \ldots \ldots \ldots \ldots \ldots \ldots \ldots \ldots \ldots \ldots \ldots \ldots \ldots \ldots \ldots \ldots$ & $0.17-0.19$ & $0.357-0.461$ & $0.320-0.369$ \\
\hline Length of terminal spike $\ldots \ldots \ldots \ldots \ldots \ldots \ldots \ldots$ & $0.041-0.053$ & $0.034-0.086$ & $0.057-0.074$ \\
\hline Vulva from posterior end $\ldots \ldots \ldots \ldots \ldots \ldots \ldots$ & - & $1.366-2.843$ & $1.62-2.30$ \\
\hline \multirow[t]{3}{*}{ Egg dimensions $\ldots \ldots \ldots \ldots \ldots \ldots \ldots \ldots \ldots \ldots \ldots \ldots \ldots \ldots \ldots \ldots \ldots$} & - & $0.086-0.123$ & $0.090-0.131$ \\
\hline & & $x$ & $\times$ \\
\hline & & $0.041-0.078$ & $0.057-0.078$ \\
\hline
\end{tabular}



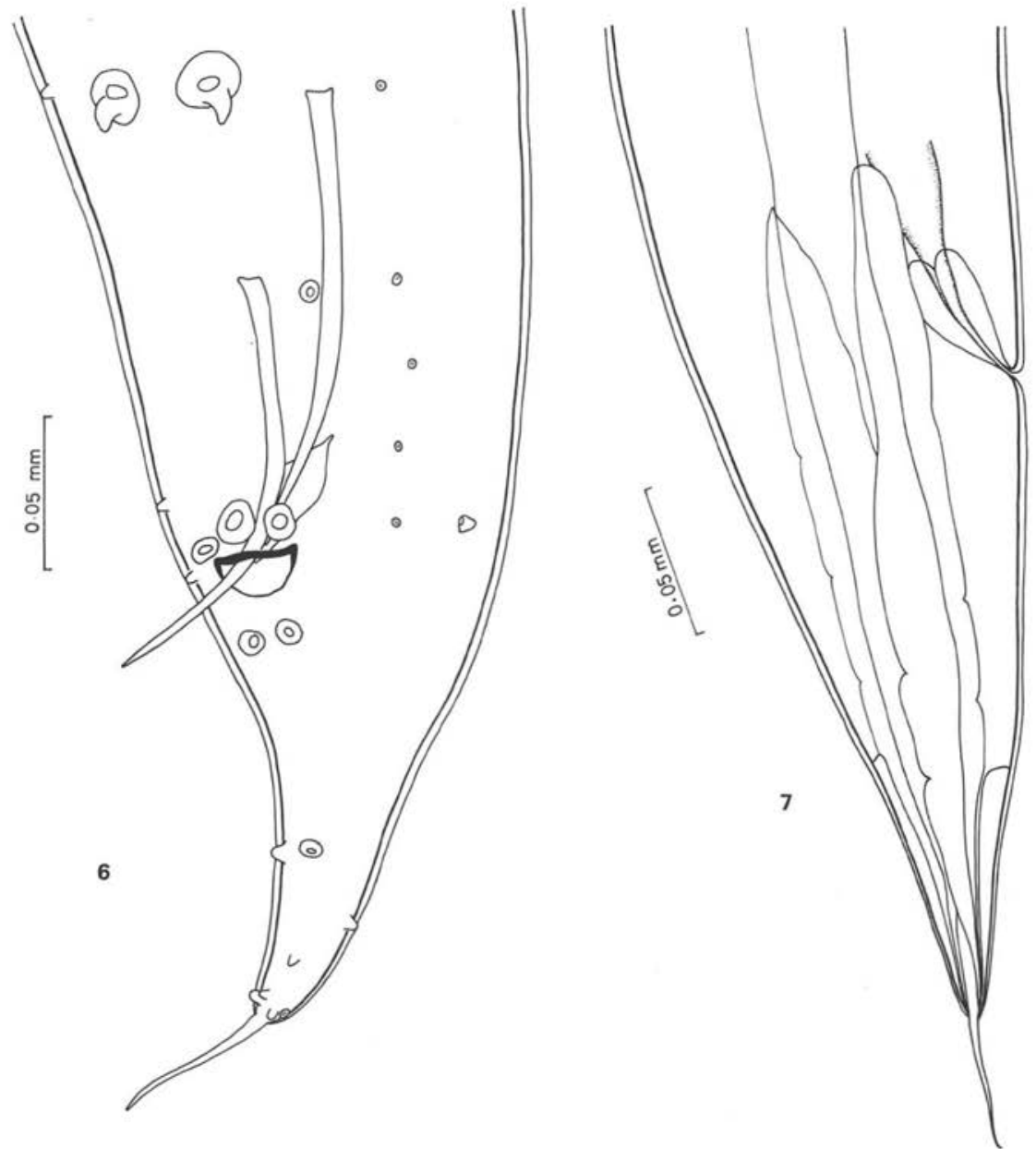

Fig. 6-7. - Aplectana uropeltidarum sp. nov.

\section{Discussion:}

A number of species belonging to the genus Aplectana have been recorded from amphibians and reptiles. 23 of them can be eliminated at the outset because they possess such features as the excretory pore being behind the oesophageal region, or the presence of a cap on the tip of each spicule, or the absence of a gubernaculum.

The specimens described here are most like Aplectana raillieti Travassos, 1925, from the intestine of Amphisbaena sp. in Brasil. They however differ from A. raillieti in body dimensions, in the number and arrangement of the caudal papillae, and Annales de Parasitologie humaine et comparée (Paris), t. 50, $\mathrm{n}^{\circ} 3$ 
in the shape of the gubernaculum. They are therefore referred to a new species which we name A plectana uropeltidarum after the host family.

\section{Type-specimens :}

The syntypes (Reg. No. RTS 38) are deposited in the Department of Zoology, University of Sri Lanka, Peradeniya.

\section{ACKNOWLEDGEMENTS}

We thank Dr. Carl Gans for the generous supply of live specimens of uropeltids and for help with the literature on this group of snakes; the Commonwealth Institute of Helminthology, St. Albans, England, for sending us, so kindly and promptly, annotated bibliographies and photocopies of papers; Dr. Sumana Wijekoon and Mrs. Visalakshi Sanmugasunderam of this department, for help in various ways; and Mr. Lionel Pereira, Mrs. Suneetha Medis and Mrs. Priscilla Pereira, for their usual efficient assistance.

\section{Bibliography}

Baylis (H. A.), 1933. - On a collection of nematodes from Malayan reptiles. Ann. Mag. nat. Hist., (Ser. 10), 11, 615-633.

Belle (E. A.), 1957. - Helminth parasites of reptiles, birds and mammals in Egypt. IV. Four new species of oxyurid parasites from reptiles. Canad. J. Zool., 35, 163-169.

Chabaud (A. G.) and Brygoo (E. R.), 1962. - Nématodes parasites de Caméléons malgaches. Deuxième note. Ann. Parasit. hum. comp., 37, 569-602.

CHEN (P.), 1966. - Aplectana chamaeleonis (Baylis, 1929) from a frog and a freshwater fish in Ethiopia. Ann. Mag. nat. Hist., (Ser. 13), 9, 333-336.

Commonwealth Institute of helminthology, St. Albans, England. - Oswaldocruzia (Nematoda): Annotated Bibliography $\mathrm{N}^{\circ} 14$ (1930-1973).

Fotedar (D. N.), 1960. - On a new species of Oxysomatium Railliet and Henry, 1913 and some notes on the genera Oxysomatium and Aplectana. J. Helminth., 34, 141150.

Freitas (J.F.T.), 1956. - Observações sôbre as espécies Sul-Americanas do gênero «Oswaldocruzia» Travassos, 1917 (Nematoda, Strongyloidea). Rev. Brasil. Biol., 16, 309-315.

GaNS (C.), 1966. - Liste der rezenten Amphibien und Reptilien : Uropeltidae. Das Tierreich, 84, 1-29.

GaNs (C.), 1973. - Uropeltid snakes, survivors in a changing world. Endeavour, 32, 60-65.

GuPTA (S. P.), 1960. - Nematode parasites of vertebrates of East Pakistan. IV. Ascaroid nematodes from amphibia, birds, and mammals. Canad. J. Zool., 38, 315-329.

GuPTA (S. P.), 1960. - Nematode parasites of vertebrates of East Pakistan. VI. Amplicaecum cacopi, Thelandros sp., Rhabdias ranae, and Oswaldocruzia melanosticti sp. nov., from frogs. Canad. J. Zool., 38, 745-750. 
HörChNer (F.), 1963. - Zur parasitenfauna der Chameleontidae und Agamidae (Squamata). Z. Parasitenk., 22, 537-544.

LaL (M. B.), 1944. - A new amphibian trichostrongylid. Current Science, 13, 104-105.

Lent (H.) et Freitas (J. F. T.), 1948. - Uma coleção de Nematódeos, parasitos de vertebrados, do Museu de Historia Natural de Montevideo. Mem. Inst. Oswaldo Cruz, $46,1-71$.

Travassos (L.), 1925. - Contribuições para o conhecimento da fauna helmintolojica dos Batraquios do Brazil. Trab. Inst. Osw. Cruz, Serv. San. Rur. Est. Rev., 1-17.

Travassos (L.), 1931. - Pesquizas helminthologicas realizadas em Hamburgo. IX. Ensaio monographico da familia Cosmocercidae Trav., 1925 (Nematoda). Mem. Inst. Oswaldo Cruz, 25, 237-298.

Walton (A. C.), 1933. - The Nematoda as parasites of Amphibia. J. Parasit., 20, 1-32.

Walton (A.-C.), 1935. - The Nematoda as parasites of Amphibia. II. J. Parasit., 21, 27-50.

Walton (A-.C.), 1941. - The finer structure of Aplectana hamatospicula (Nematoda). Proc. helm. Soc. Wash., 8, 18-21.

Yamaguti (S.), 1961. - The nematodes of vertebrates. Parts I and II. Systema Helminthum III. Interscience Publishers, New York and London, $1261 \mathrm{p}$.

Yuen (P. H.), 1963. - A new species of Oswaldocruzia Travassos (Nematoda - Trichostrongylidae) from a Malayan frog. Parasitology, 53, 85-88. 